\title{
DEVELOPMENT AND VALIDATION OF GAS CHROMATOGRAPHIC METHOD FOR ESTIMATION OF ISO-AMYL-2, CYANOACRYLATE IN PHAR MACEUTICAL DOSAGE FORM
}

\author{
Nagaraju Pappula* and L. Lokesh Kumar \\ Department of Pharmaceutical Analysis, Hindu College of Pharmacy, \\ Guntur - 522 002, Andhra Pradesh, India.
}

\section{ABSTRACT}

A simple and rapid analytical method for determination of iso-amyl-2, cyanoacrylate in pharmaceutical dosage form was developed and validated using gas chromatography (GC). The solutions of standard and the sample were prepared in methylene dichloride. GC separation was performed in about 3.649 min using a $30 \mathrm{~m} \times 0.32 \mathrm{~mm}$ I.D. (film thickness $0.25 \mu \mathrm{m}$ ) HP-5 capillary column. Helium was used as carrier gas at a flow-rate of $1 \mathrm{ml} \mathrm{min}{ }^{-1}$. After injection of the sample at inlet temperature $230^{\circ} \mathrm{C}$, the temperature of the GC oven was as follows: initial temperature was $150^{\circ} \mathrm{C}$, held for $5 \mathrm{~min}$, increased to $200^{\circ} \mathrm{C}$ at a rate of $50^{\circ} \mathrm{C} \mathrm{min}{ }^{-1}$ held for $5 \mathrm{~min}$, and finally to $240^{\circ} \mathrm{C}$ at a rate of $5^{\circ} \mathrm{C} \mathrm{min}{ }^{-1}$ and held for 3.3 min. Detector temperature is $250^{\circ} \mathrm{C}$. $2 \mu \mathrm{l}$ was injected in splitless mode. Calibration curve was linear between the concentration range $50-150 \mu \mathrm{g} / \mathrm{ml}$. The method was validated for specificity, linearity, precision, accuracy and limit of quantitation. Also, the method was applied to directly and easily to the analysis of the pharmaceutical dosage form.

Keywords: GC-FID, iso-amyl-2,cyano acrylate, HP-5 column.

\section{INTRODUCTION}

Iso-Amyl 2 Cyanoacrylate is an advanced gamma sterilized, non-pigmented, nontoxic, non-allergic, and biostatic tissue adhesive ${ }^{1}$. Chemically it belongs to the class of organic compounds known as cyanoacrylates. It helps in rapid wound closure with minimal scarring, and reduces the risk of postsurgical infection and trauma, apart from being simple to use, and showing a demonstrable safety ${ }^{2}$, thus providing effective wound healing with minimal risk. The mechanism with which Iso-Amyl 2cyanoacrylate acts is by getting converted into a polymer on coming in contact with moisture, and though, by itself, it is an inert material, it solidifies rapidly within 5-10 s. Chemical formula is $\mathrm{C}_{9} \mathrm{H}_{13} \mathrm{NO}_{2}$ and chemical weight is $167.2 \mathrm{~g} / \mathrm{mol}$ (Fig. 1: Chemical structure of Iso-Amyl-2-Cyanoacrylate).

No previous GC-FID method for the determination and quantification of Iso-Amyl-2-
Cyanoacrylate in pharmaceutical preparations in literature. Therefore, the purpose of this investigation was to develop and validate a simple, rapid, sensitive, precise, accurate and specific GC method.

\section{MATERIALS AND METHODS CHEMICALS AND REAGENTS}

Iso-Amyl-2-Cyanoacrylatewas purchased from GSK Ltd., Mumbai,and other chemicals and solvents used were of analytical grade. Amcrylate injection containing $130 \mathrm{mg}$ of IsoAmyl-2-Cyanoacrylatewas obtained from Concord Drugs Ltd., Hyderabad.

\section{Instrumentation}

The GC-FID system was performed an Agilent $6890 \mathrm{~N}$ Network GC equipped with a flame ionization detector, Agilent 7683 series auto sampler, Agilent chemstation and HP-5 column with $0.25 \mu \mathrm{m}$ film thickness $(30 \mathrm{~m} \mathrm{x}$ $0.320 \mathrm{~mm}$ I.D.). Injection and detector 
temperature is 230 and $250^{\circ} \mathrm{C}$, respectively. 2 $\mu \mathrm{l}$ was injected in split less mode. The carry gas $(\mathrm{He})$ flow-rate was kept constant during the run at $2 \mathrm{ml} \mathrm{min}^{-1}$. Nitrogen $\left(25 \mathrm{ml} \mathrm{min}^{-1}\right)$, hydrogen $\left(40 \mathrm{ml} \mathrm{min}^{-1}\right)$ and synthetic air $(400$ $\mathrm{ml} \mathrm{min}^{-1}$ ) were used as auxiliary gases for the flame ionization detector.

\section{Preparation of the standard solution}

The stock standard solution of Iso-Amyl-2Cyanoacrylatewas prepared by weigh $130 \mathrm{mg}$ drug transfer into $10 \mathrm{ml}$ of volumetric flask and dissolved in little amount of methylene dichloride (purity 99\%)and make up the volume.

\section{Preparation of the sample solution}

Exactly take the sample of Iso-Amyl-2Cyanoacrylate equivalent to $130 \mathrm{mg}$ and transfer into $10 \mathrm{ml}$ of volumetric flask and dissolved in little amount of methylene dichloride (purity 99\%) and make up the volume.

\section{RESULTS AND DISCUSSION}

Method development and optimization

The method development for the assay of IsoAmyl-2-Cyanoacrylate was based on its chemical properties. Iso-Amyl-2-Cyanoacrylate is a polar molecule and, therefore, a polar solvent methanol was used as the diluent. The capillary column coated with $5 \%$ phenyl, $95 \%$ dimethylpolysiloxane is a good choice for separationof this analyte since they elute as symmetrical peaks at a wide range of concentrations. The GC-FID parameters used in the method development were based on the boiling point. The injection port and detector temperature were set to 230 and $250^{\circ} \mathrm{C}$, respectively. Different temperature programs were investigated for GC oven. The temperature programs of the GC oven with a run time of 13 min was as follows: initial temperature $150^{\circ} \mathrm{C}$, held for $1.5 \mathrm{~min}$, increased to $240^{\circ} \mathrm{C}$ at a rate of $50^{\circ} \mathrm{C} \mathrm{min}-1$ held for $5 \mathrm{~min}$, and finally to $250^{\circ} \mathrm{C}$ at a rate of $10^{\circ} \mathrm{C} \mathrm{min}^{-1}$ and held for $3.3 \mathrm{~min}$. The head pressure was set to ensure a hydrogen flow of $40 \mathrm{ml} \mathrm{min}{ }^{-1}$. The split less mode was chosen. The solvent, column and acquisition parameters were chosen to be a starting point for the method development.

The retention time of Iso-Amyl-2Cyanoacrylate was approximately $3.649 \mathrm{~min}$ with good peak shape. No further optimisation of the method was required. Additionally, preliminary precision and linearity studies performed during the development of the method showed that the $2 \mu$ injection volume was reproducible and the peak response was significant at the analytical concentration chosen. Typical chromatogram obtained with standard Iso-Amyl-2-Cyanoacrylate is presented in Figure 2.

\section{METHOD VALIDATION Linearity}

The linearity of peak area response versus concentration for Iso-Amyl-2-Cyanoacrylate was studied between concentration range of $50-150 \mu \mathrm{g} / \mathrm{ml}$. The calibration curve constructed was evaluated by its correlation coefficient. The calibration equation from six replicate experiments, $y=415024 x(r=$ $0.9997)$, demonstrated the linearity of the method Table 1 and figure 2.

\section{Precision}

The precision of the analytic method was determined by repeatability (within-day) and intermediate precision (between-day). The RSD value for within-day precision was $\leq 3.02 \%$ and for between-day precision was $\leq 3.82 \%$ Table 2 and 3 .

\section{Accuracy (Recovery)}

To determine the accuracy of the proposed method and to study the interference of formulation additives, the recovery was checked as three different concentration levels $(75,100,125 \% \mathrm{w} / \mathrm{w})$ and analytical recovery experiments were performed by adding known amount of pure drugs to pre-analyzed samples of commercial dosage form. The percent analytical recovery values were calculated by comparing concentration obtained from the spiked samples with actual added concentrations. These values are also listed in Table 4. 
<smiles>C=C(C#N)C(=O)OCCC(C)C</smiles>

Fig. 1: Chemical structure of Iso-Amyl-2-Cyanoacrylate

Table 1: Linearity values of Iso-Amyl-2-Cyanoacrylate

\begin{tabular}{|c|c|c|c|c|}
\hline \multirow{2}{*}{$\begin{array}{c}\text { Concentration } \\
\text { (nm/ml) }\end{array}$} & \multicolumn{3}{|c|}{ Area } & \multirow{2}{*}{ Mean } \\
\cline { 2 - 4 } & Run 1 & Run 2 & Run 3 & \\
\hline 50 & 20721180 & 20438219 & 20218854 & 20459418 \\
\hline 75 & 31081769 & 31211432 & 32414362 & 31569188 \\
\hline 100 & 41442359 & 41582240 & 41282843 & 41435814 \\
\hline 125 & 51802949 & 52101199 & 51641276 & 51848475 \\
\hline 150 & 62163539 & 62282489 & 62149632 & 62198553 \\
\hline \multicolumn{4}{|c}{ Correlation coefficient } & 0.9997 \\
\hline
\end{tabular}

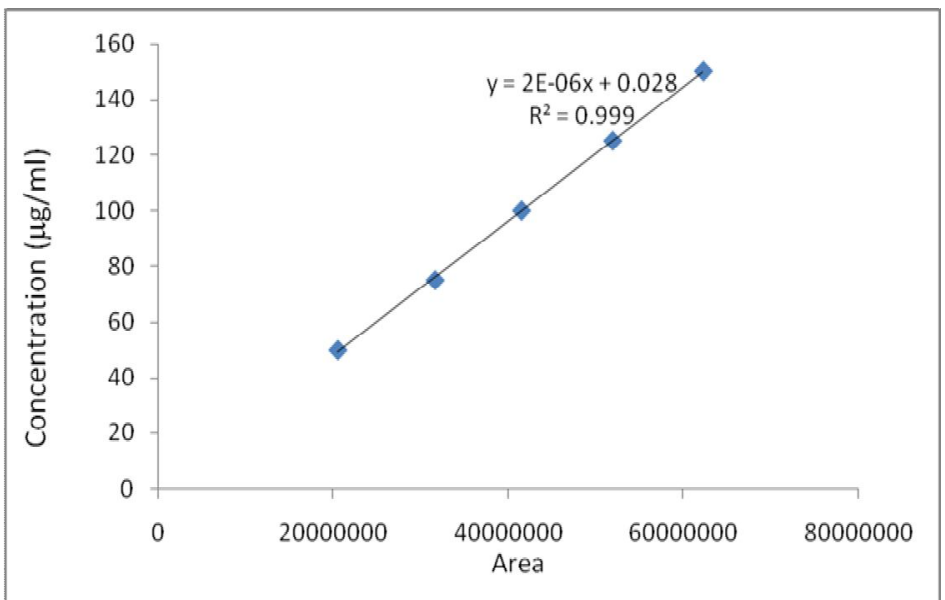

Fig. 2: Calibration curve of Iso-Amyl-2-Cyanoacrylate

Table 2: System precision 
values of Iso-amyl-2, cyanoacrylate

\begin{tabular}{|c|c|c|}
\hline Inj. No. & Area & RT \\
\hline 1 & 41511599 & 3.658 \\
\hline 2 & 41242422 & 3.629 \\
\hline 3 & 41443219 & 3.679 \\
\hline 4 & 41202044 & 3.616 \\
\hline 5 & 41342449 & 3.649 \\
\hline 6 & 41494480 & 3.611 \\
\hline Mean & 41372702 & 3.6403 \\
\hline SD & 131230.47 & 0.0263186 \\
\hline \% RSD & 0.31719 & 0.7229712 \\
\hline
\end{tabular}

Table 3: Method precision values of Iso-amyl-2, cyanoacrylate

\begin{tabular}{|c|c|c|}
\hline Inj. No. & Area & RT \\
\hline 1 & 41411598 & 3.641 \\
\hline 2 & 41554481 & 3.639 \\
\hline 3 & 41342449 & 3.604 \\
\hline 4 & 41292466 & 3.637 \\
\hline 5 & 41763219 & 3.626 \\
\hline 6 & 41142325 & 3.624 \\
\hline Mean & 41417756 & 3.6285 \\
\hline SD & 216936.53 & 0.0126853 \\
\hline \% RSD & 0.5237766 & 0.3496016 \\
\hline
\end{tabular}

Table 4: Accuracy (\% Recovery studies) values of Iso-amyl-2, cyanoacrylate

\begin{tabular}{|c|c|c|c|c|c|}
\hline \multirow{2}{*}{$\begin{array}{c}\text { Sample spike } \\
\text { (\% w/w) }\end{array}$} & \multicolumn{3}{|c|}{ Area } & \multirow{2}{*}{ Mean } & $\begin{array}{c}\text { Recovery } \\
\text { (\% w/w) }\end{array}$ \\
\cline { 2 - 4 } & Run 1 & Run 2 & Run 3 & & 89 \\
\hline 75 & 27662774 & 25941996 & 26411993 & 26672254 & 98 \\
\hline 100 & 40613512 & 40843296 & 40743481 & 40733430 & 94 \\
\hline 125 & 53875067 & 52944981 & 53105019 & 53308356 & 104 \\
\hline
\end{tabular}

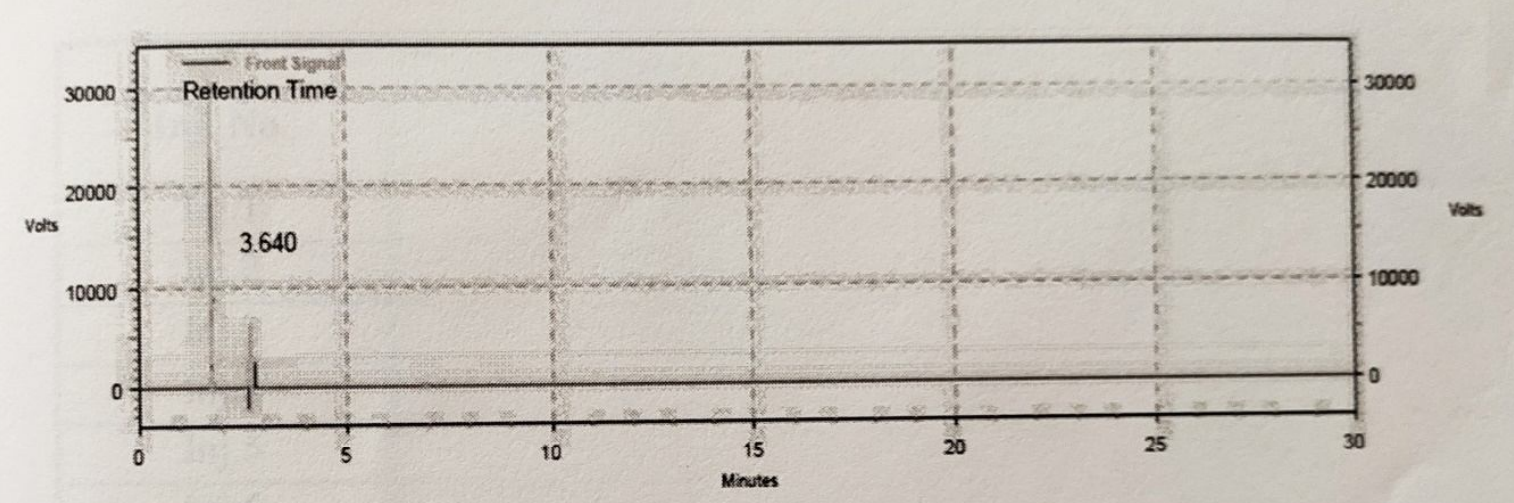

Front Signal

Results

Retention Time

3.640

Area

Area \%

Height

Height \%

41442351

$100.00 \quad 47317453$

100.00

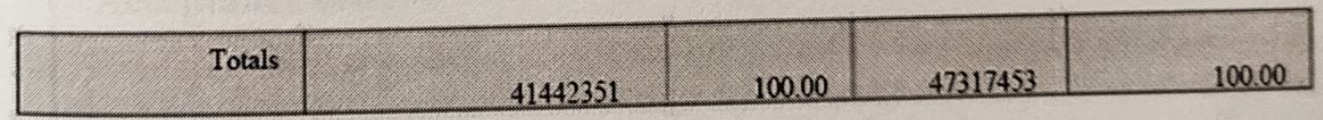

Fig. 3: Typical Chromatogram

\section{Robustness}


The robustness of an analytical method is a measure of its capacity to remain unaffected by small but deliberate variations in method parameters and provides an indication of its reliability during normal usage. It is concluded that the method is robust as it is found that the $\%$ RSD is less than 2 concerning flow rate $(1.1 \mathrm{ml} / \mathrm{min} 1.3 \mathrm{ml} / \mathrm{min})$, mobile phase ((-) 35B:65A-(+) 45B:55A) and temperature ((-) $\left.25^{\circ} \mathrm{C}-(+) 35^{\circ} \mathrm{C}\right)$.

\section{CONCLUSION}

In the present report, a simple, rapid, sensitive, reliable, specific, accurate and precise GC-FID method for the determination of iso-amyl-2, cyanoacrylate in pharmaceutical preparation was developed and validated. The method described in the present report has been effectively and efficiently used to analyzeisoamyl-2, cyanoacrylate pharmaceutical dosage form without any interference from the pharmaceutical excipients. Therefore, GC-FID method can be used for the routine QC analysis of iso-amyl-2, cyanoacrylate in pharmaceutical preparations.

\section{REFERENCES}

1. Stavropoulou C. Comparison of Cyanoacrylate Tissue Adhesives to Polytetrafluoroethylene Sutures in the Donor Site of Connective Tissue GraftsA Randomized Clinical Trial (Doctoral dissertation).

2. Devrukhkar VN, Hegde RJ, Khare SS and Saraf TA. Evaluation of isoamyl 2cyanoacrylate tissue adhesive in management of pediatric lacerations: An alternative to suturing. Annals of maxillofacial surgery. 2015;5(1):49.

3. Sameena T, Sethy SP, Patil P, Shailaja $\mathrm{K}$ and Ashraf $\mathrm{O}$. Cyanoacrylate: a bio adhesive for suture less surgery: a review. Asian Journal of Research in Chemistry. 2014;7(3):349-54. 